\title{
The impact of tourism on income inequality in developing economies: Does Kuznets curve hypothesis exist?
}

\begin{abstract}
This paper investigates the impact of tourism on income inequality in developing economies. The analysis utilizes a balanced panel data set from 1991 to 2012 on 49 developing economies around the world. The empirical findings confirm the long-run equilibrium relationship among the variables. Results from long-run elasticities indicate that tourism increases income inequality significantly. Further, the long-run elasticities on squared tourism revenue confirm the existence of Kuznets curve hypothesis between tourism revenue and income inequalities, meaning that if the current level of tourism becomes double then it will significantly reduce the income inequality in developing economies. Given these findings, our study offers significant value to the body of knowledge on the issue of tourism and income inequality in developing economies and also provides important policy implications.
\end{abstract}

Keywords: Income inequality, Tourism industry, Economic growth, Kuznets curve hypothesis, developing economies 


\section{Introduction}

For the last few decades, tourism has become one of the major forces for economic growth in many developing and developed countries. Tourism contributes to economic growth through various channels including foreign currency earnings, attracting international investment, increasing tax revenues and creating additional employment opportunities. Therefore, a wide range of literature is available that emphasizes the influence of tourism development on direct and indirect economic benefits. Most of these studies assume a relatively static and functional economy where economic growth is the highest priority, rather than a dynamic socioeconomic system. Only a few academic studies including Tosun et al. (2003) and Incera and Fernández (2015) explore the dynamic socio-economic impact of tourism. Almost all of these studies are case study driven with a theoretical orientation.

From a theoretical perspective, the tourism development has both positive and negative impacts on the income inequality of a region or country. For example, Bartik (1991) argues that tourism increases local economic activities, and greater economic growth will worsen the local income distribution. The rationality of this argument is that local growth will raise inflation and property values to a greater extent. In the same line, Papatheodorou (2004), by utilising economic geography, proposes a theoretical model indicating that the evolutionary pathway of a resort is arbitrated through the prevailing local socioeconomic structure. The author further argues that, although small traditional firms exist along with transnational companies (TNCs) by focusing on niche market, the mass market is generally dominated by large multinational conglomerates due to their reputation of better services. Therefore, a new local firm faces strong entry barriers and existing firms in the market also face severe challenges by large and financially powerful conglomerates which may have significant negative impact on local employment and income distribution. Moreover, Schilcher (2007) and Stabler et al. (2010) also claim that tourism is considered as one of the important 
industries dominated by TNCs, which have exploited the workers and resources of tourism areas/zones, repatriated of profits to their home country, commodified traditional cultures, entrenched inequality and deepened poverty.

However, tourism can be used as a means to reduce income inequality through the pro-poor impact of tourism. Pro-poor tourism is an approach which aims to ensure that tourism delivers more net benefits to the poor. It should be applied to those economies/states that are currently heavily reliant on tourism revenues. Under this approach, tourism is viewed as a tool to create enhanced opportunities, to generate mass employment and benefits to the most vulnerable groups of the society by making them involve in the production of tourism goods and services. Tourism can also be used as a tool to redistribute income since it is one of the most important sources of government revenue. However, it is crucial how the government spends these new revenues to improve the welfare of the poor (Incera and Fernández, 2015).

Since the theoretical studies on the relationship between tourism-income inequality are varied, though the empirical studies may provide more comprehensive findings. However, empirical studies concerning tourism development and income inequality are rare. To better comprehend the effects of tourism development on society, it is essential to empirically analyze how the economic outcomes from tourism development are distributed among different income groups in developing countries. Therefore, in this study, we aim to examine the role of tourism development on income inequality in 49 developing economies across the world.

There are five main contributions of our study to the tourism literature. First, to our knowledge, this is the first study that investigates the Kuznets curve hypothesis on the relationship between tourism and income inequality. The standard Kuznets curve indicates that in the initial stages of economic development there is a positive relationship between per 
capita income and inequality. However, once a country reaches to a certain level of economic development then there may be a negative relationship between per capita income and inequality. In the context of tourism and income inequality relationship, we also expect the existence of Kuznets curve hypothesis, suggesting that the tourism industry may increase income inequality at its earlier stage of development; however, it can reduce income inequality significantly once it reaches to a certain stage of development. Second, this is also a pioneer study that examines the dynamic relationship between tourism and income inequality in the panel framework. The investigation of the dynamic relationship is important since the causality between tourism and income inequality is not only running from tourism to income inequality but it can also be from income inequality to tourism because tourism related TNCs sometimes prefer to invest in unequal societies where they can exploit the local workers and resources. Third, the sample countries considered in this study, which are major tourism revenue receiving developing countries across the world. At the same time, income inequalities are more prevalent in the developing countries compared to developed ones. Therefore, findings derived from this large sample of developing countries are expected to be robust, more reliable and provide valuable policy implications.

Fourth, our study is novel in the tourism literature since we have adopted recently developed econometric techniques including the Pesaran (2004) cross-sectional dependence (CD) test, the Pesaran (2007) cross-sectionally augmented Im-Pesaran-Shin (CIPS) unit root test, Fisher-type Johansen panel co-integration test and Dumitrescu and Hurlin (2012) heterogeneous non-causality test. Fifth, our final contribution is to employ a multivariate framework instead of a bivariate model to the tourism-income inequality nexus literature. The bivariate model is often criticized due to the omitted variables biasness (Stern, 1993). Furthermore, excluding relevant variable(s) makes the estimates not only spurious and inconsistent but cause and effect relationship can also result from neglected variables. It is 
possible that the introduction of a third or more variables in the regression framework may not only alter the direction of relationship but also the magnitude of the estimates (Loizides and Vamvoukas, 2005). Therefore, investigating the dynamic relationship using a more generalized multivariate model may provide robust and reliable results. Along with tourism, we introduce FDI, GDP per capita and trade openness into our econometric model since these variables also have a significant impact on income inequality. In addition, we also confirm the robustness of our results by incorporating other potential determinants of income inequality into the model such inflation, personal remittance inflows, travel and tourism competitiveness index and unemployment along with FDI, GDP per capita, trade openness and tourism.

The remainder of this paper is organized as follows. The next section presents the critical review of the literature focusing on methods and findings. Section 3 discusses the proposed methodology and econometric methods adopted. Section 4 presents the preliminary and empirical results. Finally, Section 5 provides the conclusion and policy implications.

\section{Literature Review}

Over the last few decades, studies related to tourism development have generally emphasized the modernization perspective which focuses on various direct and indirect positive aspects of tourism (Archer and Fletcher, 1996; Fletcher, 1989; Huse et al., 1998). Although these studies have made significant contributions to tourism development research, their application, relevance, and validity are seriously restricted since most of these studies ignore the distribution of economic gains and burdens of tourism. To better understand the effects of tourism development on a community, it is necessary to examine how economic outcomes of tourism development are distributed among different income groups in tourism services- 
dependent communities. However, there are few studies regarding the equitable distribution of economic benefits associated with tourism and recreation development.

Wen and Tisdell (1997) is one of the pioneer studies that empirically examine the impact of international tourism on income inequality in China. Analyzing both demand-side and supply-side indicators of tourism, the study finds that tourism increases regional inequality among the various provinces in China. Tosun et al. (2003) investigate the relationship between tourism and income inequality. Considering Turkey as a case study, the study provides evidence that tourism has little contribution to the overall economic development of the country. Instead, it has increased the rate of economic growth at the expense of equality among coastal and rural regions and classes of various income groups. Marcouiller et al. (2004) have examined the relationship between natural amenities and income distribution for the US lake states. Using a Gini coefficient as a measure of income distribution, the study suggests that certain types of natural amenities particularly water-based resources are clearly related to increased income inequality among various income classes.

Evaluating the performance of community based tourism enterprises in Kenya, Manyara and Jones (2007) examine the impact of tourism on poverty alleviation and income inequality. The authors use individual in-depth semi-structured interviews with enterprise managers, community leaders, tourism academics, government and non-government officials, and focus groups with community members. The findings of the study emphasize that tourism does not make any significant contribution toward reducing poverty and income inequality in Kenya. Blake et al. (2008) investigate the distributional impact of tourism on different households in the Brazilian economy. The study employs a computable general equilibrium (CGE) model and finds that the influences of tourism on all income groups are positive. However, some higher income groups enjoy a higher benefit than the lower income households. 
Scheyvens and Momsen (2008) examine the role of tourism on economic growth, poverty reduction and income inequality. Considering some selected small island developing states (SIDS) as case studies, the study argues that although tourism has a significant contribution to economic development, it does not have a considerable influence on poverty alleviation in the selected countries. In fact, in some states, tourism increases existing income inequalities. Lee and O'Leary (2008) explore the determinants of income inequality in selected nonmetropolitan communities in the US. Using data from 1990 to 2000, the results of the study suggest that tourism and recreation-related variables such as tourism and recreation employment, and tourism and recreation earnings are factors that make a considerable contribution to income inequality. A similar finding is also reached by Lee (2009). The author investigates the trends and patterns of income inequality for tourism servicesdependent states in the US. Analyzing data from the Population and Housing Census of 1990 and 2000, the study reveals that tourism-dependent states have higher income inequality than non-tourism dependent states. Moreover, income inequality has increased faster in tourism dependent states than for the US as a whole.

Sharpley and Naidoo (2010) analyze whether tourism has an appreciable impact on reducing poverty in Mauritius. Reviewing the concept of pro-poor tourism, the study concludes that although tourism can promote short-term economic benefits to the poor, it is unlikely to make a long-term considerable contribution to poverty reduction. However, Jiang et al. (2011) report a different finding for SIDS in Asia-Pacific, the Caribbean and Africa. The study used the human development index (HDI) and under five mortality rates as a proxy for poverty alleviation. The results of the study suggest that the states which have higher tourism intensity enjoy a higher standard of living, along with a higher HDI and lower infant mortality. Recently, Croes (2014) examines the impact of tourism on absolute poverty in the Central American developing countries of Nicaragua and Costa Rica. Employing the Granger 
causality test, the findings of the study indicate that tourism helps to reduce absolute poverty in both of the sample countries.

At the micro level, several descriptive and empirical studies are available that investigate the impact of tourism on poverty in rural areas. Holden et al. (2011) explore how the local people of Elmina, Ghana have benefited from the tourism activities. Based upon interpretive and participatory fieldwork, the study provides evidence that the potential of tourism to reduce poverty is high, but remains hindered by major barriers to entrepreneurship development and employment within the sector. Considering a lakeshore community in Malawi named Nkhata Bay, Gartner and Cukier (2012) explore whether tourism employment is a sufficient tool for alleviating poverty. From both qualitative and quantitative analyses, the study provides little support in favor of the argument that employees related to tourism activities and their households have experienced a significant improvement in poverty conditions.

Job and Paesler (2013) analyze the nature-based tourism and standard of living in the Wasini Island of Kenya. Using economic impact analysis, the results show that an increased income from tourism leads to improved standards of living. Truong et al. (2014) investigate whether tourism has any significant impact on poverty reduction among the poor in Sapa, Vietnam. The study conducted semi-structured interviews with local residents and key stakeholders. The analysis of the study suggests that although tourism is one of the contributors to poverty alleviation for the poor in Sapa, the non-poor and tour operators are the major beneficiaries from the local tourism activities.

Very recently, Incera and Fernández (2015) examine the impact of inbound tourism on income distribution in the regional developed economy of Galicia in Spain for the year 2008. Employing a social accounting matrix (SAM) model, the authors provide evidence that highincome households enjoy a higher benefit from tourism than low income ones. Therefore, the 
study concludes that inbound tourism causes a slight increase in income inequality in Galicia. The same finding is also confirmed by Pelizzo and Kinyondo (2015) in the case of Tanzania. Their analysis is based on primary and secondary data which is collected from various institutional sources and several interviews conducted with the officials and executives from the Ministry of Natural Resources and Tourism, Tanzania. It suggests that tourism-led growth could not reduce income inequality due to three factors: vertical integration, foreign ownership and insufficient wage packages for workers in the tourism sector. However, Li et al. (2015) report different findings in the case of China. Employing a dynamic panel data analysis on coastal and inland China, the study seeks to investigate whether tourism development reduces or increases regional inequality in China. The study uses the conditional convergence model of Barro and Sala-i-Martin and finds that tourism has a stronger positive impact on economic development in inland areas (a less developed region) than in coastal areas (a developed region), which implies that tourism-induced growth can decrease regional inequality in China. Similarly, a very recent study by Li et al. (2016), document that the tourism reduces regional inequalities in China. Further, authors suggest that the domestic tourism has more impact than international tourism on reducing regional inequalities.

This review suggests that the relationship between tourism development and income inequality varies across countries and methods. Furthermore, most of the studies have been conducted on a context of a single country using survey data for a specified time period, and no study is found using panel frameworks. In addition, since most of the empirical studies address the issue within an individual country by using a standard regression framework, their findings cannot be generalized since the results suffer from an endogeneity problem and findings from one particular country may not applicable to the another country. Hence, this study is a modest attempt to address these limitations, and to contribute to the body of 
knowledge in this area providing potential policy implications for sustainable economic growth.

\section{Data and methodology}

\subsection{Data and measurement}

In this section, we aim to provide the description of the variables and their measurement. The selection of the sample period and the countries are based on the availability of the annual data from 1991 to 2012 (i.e. 22 observations for each cross-section or country). This implies that we use a balanced panel data set on 49 developing economies across the world. The considered developing economies are; Argentina, Armenia, Bangladesh, Belarus, Brazil, Bulgaria, China, Colombia, Costa Rica, Dominican Republic, Ecuador, Egypt, El Salvador, Ethiopia, Fiji, Guatemala, Honduras, Hungary, India, Indonesia, Iran, Jordan, Kazakhstan, Kyrgyz Republic, Macedonia, Malawi, Malaysia, Mali, Mexico, Moldova, Nigeria, Panama, Paraguay, Peru, Philippines, Romania, Rwanda, Sierra Leone, South Africa, Sri Lanka, Thailand, Tunisia, Turkey, Uganda, Ukraine, Venezuela, Vietnam, Zambia and Zimbabwe. The measurement of the variables is described below.

In this study, income inequality (IIE) is measured through the Gini coefficient, the higher (lower) the Gini value then the higher (lower) is the income inequality in the country. Gross domestic product per capita (GDPPC) is measured in constant 2005 US dollars, foreign direct investment (FDI) net inflows are measured as a percentage of GDP, trade openness (TO), which is total exports and imports as a percentage of GDP and finally, tourism revenue (TR) are measured as a direct and indirect contribution of the tourism sector to the GDP. The considered time series data on GDP per capita, FDI and trade openness are obtained from the World Development Indicators (WDI) online database published by the World Bank while data on Gini coefficient and tourism revenue are obtained from the Standardized World 
Income Inequality Database (SWIID) and the World Travel and Tourism Council (WTTC), respectively.

A number of authors suggest normalizing the data series before the application of any econometric model (e.g. Alam et al., 2016, Bhattacharya et al., 2016; Paramati et al., 2016). Therefore, it is important to normalize the data series and transform all of the variables data into a uniform measurement before employing any statistical model. Since the variables of this study are measured differently, particularly income inequality is measured as an index and GDP per capita is measured in monetary units while all other variables are measured in percentages. Therefore, the transformation of the data series into natural logarithms helps to avoid the problems associated with their distributional properties. The log conversion of series is a preferred approach since each of the estimated coefficients in regression model can be interpreted as elasticities.

\subsection{Model specification}

In this study, we use panel econometric models for the analysis, since they have many advantages when compared to cross-section and time series models. For instance, a panel data set can provide more information and can also control individual heterogeneity, which will then increase the efficiency of the econometric estimation. One of the important properties of the panel data set is to include as many cross-sections (countries) as possible with a reasonable time span of observations, since this will enrich the outcome of the analysis. These estimates are, therefore, more reliable and provide stable parameters. Panel data estimation can also help to overcome the problems associated with deficient distributions and stationarity issues that are often experienced in a time series framework (shorter 
duration). ${ }^{1}$ In the estimation procedure, income inequality is served as a dependent variable while FDI inflows, GDP per capita, trade openness and tourism revenue are served as independent variables in the model. The basic and general framework for identifying the potential determinants of income inequality can be written as follows:

$I I E_{i t}=f\left(F D I_{i t}, G D P P C_{i t}, T O_{i t}, T R_{i t}, v_{i}\right)$

Eq. (1) can be parameterized as below.

$I I E_{i t}=F D I_{i t}^{\beta_{1 i}} G D P P C_{i t}^{\beta_{2 i}} T O_{i t}^{\beta_{3 i}} \operatorname{TR}_{i t}^{\beta_{4 i}} v_{i}$

The following equation can be derived by taking the natural logarithms of Eq. (2). Where lower case letters denote the natural log of upper case letters and adding a random error term can produce the following equation:

$i i_{i t}=\beta_{1 i} f d i_{i t}+\beta_{2 i} g d p p c_{i t}+\beta_{3 i} t o_{i t}+\beta_{4 i} t r_{i t}+v_{i}+\varepsilon_{i t}$

In Eq. (3), countries are denoted by the subscript $i \quad((i=1, \ldots \ldots, N)$ and $t$ denotes time period $(t=1, \ldots \ldots, T)$. This equation is a fairly general specification, which accounts for individual country fixed effects $(v)$ and a stochastic error term $(\varepsilon)$. The detailed discussion on the empirical models is provided below.

\subsubsection{CD and unit root tests}

We first aim to identify whether the given series is cross-sectional dependent or independent. ${ }^{2}$ For this purpose, we employ the Pesaran (2004) CD test. This is a significant issue to be addressed before the use of panel unit root tests. The conventional unit root tests

\footnotetext{
${ }^{1}$ Alam and Paramati (2015) suggest that the panel data analysis provide more reliable results than those of the time series analysis when each cross-section of the time series is smaller.

${ }^{2}$ Several authors (e.g. Bhattacharya et al., 2016; Paramati et al., 2016; Alam et al., 2015) argue the significance of cross-sectional dependence in the analysis.
} 
are ineffective, due to lower power, when they are applied on the series that has a crosssectional dependence. Therefore, in this study, based on the evidence produced by the Pesaran (2004) CD test, we apply the Pesaran (2007) CIPS unit root test which is established on the assumption of cross-sectional dependence. This unit root test is employed to investigate the order of integration of the variables. This is a prerequisite for applying the panel co-integration model. If all of the variables are integrated of the same order that is, I (1), then this indicates that all of the variables have a unit root at levels and stationary at their first order differentials. This suggests that these variables, as a group, may have a long-run equilibrium relationship.

\subsubsection{Panel co-integration technique}

We employ a panel co-integration technique to explore the long-run equilibrium relationship among the variables of income inequality, FDI inflows, GDP per capita, trade openness and tourism revenue across a panel of 49 developing economies. The panel co-integration technique is more useful if the time series element of each cross-section is shorter. Due to these advantages, researchers (e.g. Alam and Paramati, 2015) started using the panel cointegration approach to examine the long-run equilibrium relationship among the variables. In this study, we apply a Fisher-type Johansen co-integration methodology which is proposed and developed by Maddala and Wu (1999).

The Fisher-type panel co-integration methodology uses the Johansen's (1991) approach. Maddala and $\mathrm{Wu}(1999)$ argue that this panel co-integration test is more robust than the conventional co-integration tests which are based on the Engle-Granger two-step approach. This method uses two ratio tests such as the trace test and the maximum eigenvalue test to identify the number of co-integrating vectors. The findings of both the trace and max-eigen tests can be utilized to determine the presence of co-integrating vectors. However, these two 
tests may not always provide an equal number of co-integrating vectors. If both tests do not provide the same number of co-integrating vectors, then we can draw the conclusions based on the max-eigen test since it carries the independent analysis on each eigenvalue.

\subsubsection{Long-run elasticities}

Further, we estimate a single co-integrating vector, based on Eq. (3) to investigate the longrun income inequality elasticities. In regard to the panel dataset, the application of ordinary least squares (OLS) on Eq. (3) is asymptotically biased and its distribution relies upon a nuisance parameter. Pedroni $(2000,2001)$ argues that in the course of regression estimation, the nuisance parameters can result due to the presence of serial correlation and endogeneity among the regressors. Therefore, to address these issues, we employ a FMOLS model. This approach utilizes a non-parametric method to address the issue of endogeneity and serial correlation. Therefore, the FMOLS model is utilized to estimate the long-run elasticities of income inequality.

\subsubsection{Heterogeneous panel causality test}

We explore the short-run dynamic bivariate panel causality among income inequality, FDI, GDP per capita, trade openness and tourism revenue by using a model that accounts for heterogeneity across the cross-sections. A simple approach is proposed by Dumitrescu and Hurlin (2012) for testing the null hypothesis of homogeneous non-causality against the alternative hypothesis of heterogeneous non-causality. ${ }^{3}$ This test has to be applied on a stationary data series using the fixed coefficients in a vector autoregressive (VAR) framework. The significance of this test is that it allows for having a dissimilar log structure and also heterogeneous unrestricted coefficients across the cross-sections under both the

\footnotetext{
${ }^{3}$ The conventional Granger causality test does not allow the coefficients to vary cross the cross-sections. Therefore, the recent literature (e.g. Bhattacharya et al., 2016 and Paramati et al., 2016) has started to use the heterogeneous panel non-causality test which allows coefficients to vary across the cross-sections.
} 
hypotheses. Under the null hypothesis, no causality in any cross-section is tested against the alternative hypothesis of causality at least for a few cross-sections. The Wald statistics for testing Granger non-causality are computed for each of the cross-sections separately. Then, the panel test value is acquired by taking the cross-sectional average of individual Wald statistics. Dumitrescu and Hurlin (2012) argue that this panel test value converges to a normal distribution under the homogeneous non-causality hypothesis when $T$ tends to infinity first and then $N$ tends to infinity.

\section{Results and discussion}

\subsection{Preliminary analysis}

We present average annual growth rates on the considered variables for the period of 19912012. These growth rates are displayed in Table 1. The results show that, out of 49 developing economies, 26 countries have average positive growth rates for income inequality. The highest positive average growth rates for income inequality are attained by Ukraine (2.32\%), Sri Lanka (1.86\%), Rwanda (1.80\%) and Macedonia (1.72\%). This implies that the positive growth of income inequality is a concern since it indicates the widening of income disparities in those countries while negative growth rates suggest the reduction of income inequality over the period. Similarly, the average growth rates on FDI inflows indicate that only two countries (Ecuador and Indonesia) have negative growth rates while all other countries have significant positive growth rates during the study period. In the case of GDP per capita, the highest GDP per capita is achieved by China $(9.53 \%)$, Vietnam $(5.62 \%)$ and India (5.09\%) while some other countries experienced negative per capita growth rates such as the Kyrgyz Republic, Moldova, Ukraine and Zimbabwe. Several countries have shown significant positive growth rates in international trade. More specifically, 43 countries have displayed positive growth in trade openness while only six countries have negative 
growth rates during the study period. Finally, the considered sample countries have shown tremendous positive average growth rates in tourism revenue, with the highest growth rates obtained by Ukraine, Belarus, Iran, Moldova, Rwanda and Malawi. However, six countries (Brazil, Bulgaria, China, Ecuador, India and Indonesia) have negative growth rates. Overall, the average growth rates across the variables indicate that the income inequality is being significantly reduced while FDI inflows and tourism revenue are substantially increasing over time.

\section{[Insert Table 1 here]}

Table 2 presents mean statistics on individual countries for the 1991-2012 period. The results suggest that the income inequality across the countries varies significantly. The income inequality is higher in South Africa (56.87), Zimbabwe (53.66), Zambia (51.77), Peru (51.14) and Honduras (50.03) while some other countries have relatively lower income inequality including: Belarus (26.26), Hungary (28.58), Romania (28.84), Bulgaria (29.52) and Ukraine (29.99). Similarly, the average GDP per capita is higher for Hungary (9488.38\$), Mexico (\$7526.92) and Turkey (\$6478.55) while it is significantly lower in the case of Ethiopia (\$163.37), Malawi (\$219.40), Rwanda (\$265.58) and Uganda (\$295.49). Among these 49 sample countries, 14 countries have less than $\$ 1000$ GDP per capita while only six countries have more than $\$ 5000$. For the same period (1991-2012), the world's average GDP per capita is $\$ 6796$. This indicates that only two countries, out of 49 developing countries, have higher GDP per capita than that of world's average. Finally, the average tourism revenue as a percentage of GDP is higher for Fiji (32.49\%), Jordan (21.70\%) and Bulgaria (18.14\%) while it is lower for Paraguay (3.43\%) and Macedonia (3.85\%). The results on summary statistics on individual countries indicate that the majority of the countries are suffering from higher income inequality and have significantly lower per capita income. 


\section{[Insert Table 2 here]}

We also present consolidated statistics on panel data set. These results are shown in Table 3. The results show that the average income inequality across the sample countries is about 41.40\%. This implies that these countries have significant higher income inequality during the study period. The average FDI inflows against the GDP are 3.17\% while GDP per capita is $\$ 2545$. However, the average trade openness is substantially higher at $74.88 \%$. Finally, tourism revenue account for 9.5 percent of the GDP.

\section{[Insert Table 3 here]}

Table 3 also presents unconditional correlations on the panel data set. These results show that income inequality is negatively correlated with all of the variables such as FDI inflows, GDP per capita, trade openness and tourism revenue. This means that FDI inflows, increasing GDP per capita, trade openness and tourism revenue are working in favor of reducing income inequalities across the sample countries. However, it is not possible to draw any conclusions solely based on the unconditional correlations. Therefore, we proceed to the rigorous analysis in the following sections. ${ }^{4}$

\subsection{Results of CD and CIPS tests}

The results of CD and CIPS tests are documented in Table 4. The CD results show that the null hypothesis of cross-sectional independence is strongly rejected at the $1 \%$ significance level for all of the variables (IIE, FDI, GDPPC, TO and TR). Based on these results, we establish that all of our considered variables have cross-sectional dependence. Due to the presence of cross-sectional dependence in the data series, the application of conventional unit root tests becomes invalid since these tests rely on the assumption of cross-sectional independence. Therefore, to overcome this issue, we apply a recently developed CIPS unit

\footnotetext{
${ }^{4}$ Our results establish that there is no multicollinearity problem in the model.
} 
root test which performs under the assumption of cross-sectional dependence in the data series. The CIPS unit root test results on level data indicate that the null hypothesis of the unit root cannot be rejected for all of the variables at the 5\% significance level. However, at first order difference, the null of non-stationary can be rejected at the $1 \%$ significance level for all of the variables. The CIPS unit root test results suggest that all of the variables are nonstationary at levels and stationary at their first order differences. As a result, all of the variables are integrated of order I (1). These results provide some indication that there may be a co-integration relationship among these variables in the long-run. We, therefore, investigate this in the following section using the panel co-integration methodology.

\section{[Insert Table 4 here]}

\subsection{Results of co-integration technique}

The CIPS unit root test results confirm that all of the variables have the same order of integration i.e. I (1). This is an indication of a long-run relationship among the variables. Therefore, to explore the long-run equilibrium relationship among the considered variables, we employ the Fisher-type Johansen panel co-integration test. The results of this test are displayed in Table 5. The appropriate lag length for this analysis is chosen based on the SIC criterion. It is also confirmed that the selected lag length residuals are free from serial correlations. Under this test, the null hypothesis of no co-integration is tested against the alternative of co-integration. The findings of this test on the trace statistic and maximum eigen statistic indicate that the null hypothesis of no co-integration is strongly rejected at the $1 \%$ significance level. This implies that there is a significant long-run equilibrium relationship among the variables such as income inequality, FDI inflows, GDP per capita, trade openness and tourism revenue in developing economies.

\section{[Insert Table 5 here]}




\subsection{Results of long-run income inequality elasticities}

The co-integration test results which we presented above do not indicate whether FDI inflows, GDP per capita, trade openness and tourism revenue have a positive or negative effect on income inequality across the considered sample countries. Therefore, we apply the FMOLS $^{5}$ model to examine the impact of these variables on income inequality in the longrun. As we previously mentioned, all of the variables in this study are measured in natural logarithms and are non-stationary at their levels. Therefore, resulting coefficients from the long-run co-integrating vector can be explained as long-run elasticities. This technique provides robust results since it accounts for serial correlation and endogeneity in the analysis. The results of the FMOLS model are documented in Table 6. The findings show that FDI inflows, trade openness and tourism revenue have a significant positive impact on income inequality while GDP per capita has a negative impact. More specifically, a $1 \%$ increase in FDI inflows, trade openness and tourism revenue raises income inequality by $0.003 \%$, $0.009 \%$ and $0.017 \%$, respectively. On the other hand, a $1 \%$ increase in GDP per capita decreases income inequality by $0.047 \%$. All of the variables are statistically significant.

Further, we examine whether Kuznets curve hypothesis exists between tourism revenue and income inequality in developing economies. Therefore, in this study, we aim to see whether further growth in tourism revenue (in future) decreases income inequality in developing economies. For this purpose, we squared the tourism revenue and included as additional variable in the analysis. The results show that a $1 \%$ raise in squared tourism revenue decreases income inequality by $0.115 \%$. This finding implies that further growth of tourism revenue in future will lead to reduce the income inequality in developing economies. This

\footnotetext{
5 The previous studies (e.g. Alam et al., 2016; Paramati et al., 2016a, Paramati et al., 2016b) indicate the significance of panel FMOLS model for estimating the long-run elasticities.
} 
means that further expansion of tourism sector will assist the policy makers and governments to reduce the income inequalities in those economies.

\section{[Insert Table 6 here]}

\subsection{Robustness check}

For the purpose of robustness check, we add other potential determinants of income inequality into the model such as inflation (INF), personal remittance inflows (PR), travel and tourism competitiveness index (TTR) and unemployment (UNE) ${ }^{6}$ along with FDI, GDPPC and TO, TR. The analysis was carried out using the fixed effect model and the results are displayed in Table $7 .{ }^{7}$ The results show that GDPPC, inflation, tourism revenue, travel and tourism competitiveness index and unemployment have a significant positive impact on the income inequality while trade openness has a negative effect but not statistically significant. These additional results also suggest that tourism revenue increases income disparity in developing economies. Given these results we argue that our findings are robust and provided consistent results in terms of the effect of tourism on income inequality in developing economies. $^{8}$

\section{[Insert Table 7 here]}

\subsection{Results of heterogeneous panel non-causality test}

In this section, we aim to explore the dynamic short-run causalities among income inequality, FDI inflows, GDP per capita, trade openness and tourism revenue by employing the

\footnotetext{
${ }^{6}$ Inflation rate is calculated using the consumer price index; the personal remittance inflows are measured as percentage of GDP while travel and tourism competitiveness is an index and finally unemployment is the percentage of total labor force. The data on INF, PR and UNE are collected from World Bank while data on TTR is sourced from the World Economic forum.

${ }^{7}$ Since TTC data is only available from 2007 so we have carried our analysis using annual data from 2007 to 2012. In this analysis, we have excluded Belarus, Fiji, Iran, Rwanda, Sierra Leone and Zimbabwe due to unavailability of data.

${ }^{8}$ Given the short time period of this analysis (2007-2012), we could not examine the Kuznets curve hypothesis. Further, the detailed discussion on this additional analysis is avoided to conserve the space in the paper.
} 
Dumitrescu and Hurlin (2012) panel non-causality test. The significance of this approach is that it allows for all the coefficients to be different across the cross-sections. This test also requires that all of the variables are stationary. Therefore, we apply them on the first difference of the series. The causality test results are reported in Table 8. The short-run noncausality test results show the evidence of feedback (bidirectional) relationship between income inequality and GDP per capita. This means that these variables have a significant feedback impact on each other in the short-run. This can be further interpreted that an increase in GDP per capita leads to reduced income inequality and a decrease in income inequality further raises GDP per capita. Our results also disclose the evidence of unidirectional causality that runs from FDI inflows to income inequality and income inequality to tourism revenue. This indicates that FDI inflows cause income inequality while income inequality affects tourism revenue. This means that the benefits that are accrued from FDI inflows are not able to be distributed equally to all sections of society. Similarly, due to the presence of income inequality, some wealthy segments of society are able to investment more in the tourism sector which eventually increases tourism revenue. As a result, income inequality is affecting tourism revenue in developing economies.

\section{[Insert Table 8 here]}

\section{Conclusion}

For the last two decades, the tourism industry has significantly grown across both developed and developing economies. Given the significance of the tourism industry in terms of additional employment opportunities, income earnings, tax revenues and foreign exchange reserves, it has become an important sector for the economic development and prosperity of any economy in the world. For instance, international tourist arrivals have increased from 550 million to 1123 million during the 1995-2013 (WDI, 2015). Furthermore, global tourism revenues have increased from 3705 to 11859 billion US dollars from 1988-2014. During the 
same period, the tourism sector has increased its employment opportunities from 183 million to 277 million (WTTC, 2015). This indicates the significance of tourism industry across the world. Despite its significance for economic development, it is often asserted that the tourism industry increases income inequality among individuals. This, therefore, motivated us to empirically examine the impact of tourism on income inequality in a panel of 49 developing economies across the world during 1991-2012. Our empirical results confirm the long-run equilibrium relationship among the selected variables. Similarly, the long-run elasticities indicate that tourism increases income inequality in developing economies. However, our results on squared tourism revenue indicate that if the tourism industry becomes double the current level then it significantly reduces income inequality.

Considering the positive relationship between the tourism industry and income inequality at its current phase of development in the selected developing economies, we offer several policies in order to ensure sustainable tourism led economic growth. For instance, one of the reasons for the wider disparity between poor and rich sections of the society in these selected countries could be the oligopolistic market nature. The current tourism service providers may be formed into an oligopoly market where the supply of tourism services such as accommodations, travel and other services are solely managed by only a few multinational corporations (MNCs). If this is the case, then small and medium enterprises (SMEs) at local level will not be able to compete with these large conglomerates and may quit their businesses which will eventually lead to an unequal income distribution. Therefore, policy makers and government officials in these economies should initiate appropriate policies and offer various financial and non-financial supports that will assist local SMEs to survive along with large MNCs.

Further, we argue that the benefits of tourism development may only be confined to an elite class of people in society such as the owners of the tourism service providers, entrepreneurs, 
investors and managers of tourism enterprises. In Addition, tourism related business enterprises may create only low salaried jobs in the local communities and exploit their services and resources which eventually increase the income inequality in any given society. Given this argument, the governments of these developing economies should initiate effective redistribution policies. For instance, taxes could be increased on the profits that are generated by providing tourism related services. These additional revenues could then be redistributed among the low income earning communities through various social-welfare schemes. It is also important to provide training services to the unskilled labor those who are working in tourism related services. Increasing their training and skills will give them an opportunity to bargain their salaries with entrepreneurs. Finally, governments also need to update minimum wage policies periodically so that the people those who are earning low salaries can significantly benefit from it. In such a way, the tourism industry may reduce rather than increase income inequalities in developing economies.

Given these policy options, we also highlight some future research directions. As we discussed earlier, due to unavailability of data on travel and tourism competitiveness index we could not examine the Kuznets curve hypothesis. Therefore, we recommend for future research to focus on the tourism competitiveness index if data becomes available at least for reasonable longer time period. This analysis may offer more precise guidelines to develop sustainable tourism policies for developing economies since this index is developed using the ground level information of tourism sector. Further, future studies may also compare the impact of foreign vs domestic tourism investments on income inequality in the context of developing economies. The comparison will also help the policymakers to understand the importance of local and foreign investment in order to improve income distribution of the societies where the tourism industry plays a significant role for economic development. 


\section{References}

Alam, M.S., \& Paramati, S.R. (2015). Do oil consumption and economic growth intensify environmental degradation? Evidence from developing economies. Applied Economics, 47, 5186-5203.

Alam, M.S., Paramati, S.R., Shahbaz, M., \& Bhattacharya, M. (2015). Dynamics of Natural Gas Consumption, Output and Trade: Empirical Evidence from the Emerging Economies. Monash University, Department of Economics, Discussion Paper Series 21/15.

Alam, M.S., Paramati, S.R., Shahbaz, M., \& Bhattacharya, M. (2016). Natural gas, trade and sustainable growth: Empirical evidence from the top gas consumers of the developing world. Applied Economics, 1-15 (accessed online).

Archer, B., \& Fletcher, J. (1996). The economic impact of tourism in the seychelles. Annals of tourism research, 23(1), 32-47.

Bartik, T.J. (1991). Who benefits from state and local economic development policies? Books from Upjohn Press.

Bhattacharya, M., Paramati, S.R., Ozturk, I., \& Bhattacharya, S. (2016). The effect of renewable energy consumption on economic growth: Evidence from top 38 countries. Applied Energy, $162,733-741$.

Blake, A., Arbache, J.S., Sinclair, M.T., \& Teles, V. (2008). Tourism and poverty relief. Annals of Tourism Research, 35(1), 107-126.

Croes, R. (2014). The role of tourism in poverty reduction: An empirical assessment. Tourism Economics, 20(2), 207-226.

Duffy, R. (2013). A trip too far: Ecotourism, politics, and exploitation: Earthscan.

Dumitrescu, E.-I., \& Hurlin, C. (2012). Testing for granger non-causality in heterogeneous panels. Economic Modelling, 29(4), 1450-1460.

Fletcher, J.E. (1989). Input-output analysis and tourism impact studies. Annals of tourism research, 16(4), 514-529.

Gartner, C., \& Cukier, J. (2012). Is tourism employment a sufficient mechanism for poverty reduction? A case study from nkhata bay, malawi. Current Issues in Tourism, 15(6), 545-562.

Holden, A., Sonne, J., \& Novelli, M. (2011). Tourism and poverty reduction: An interpretation by the poor of elmina, ghana. Tourism Planning \& Development, 8(3), 317-334.

Huse, M., Gustavsen, T., \& Almedal, S. (1998). Tourism impact comparisons among norwegian towns. Annals of Tourism Research, 25(3), 721-738.

Incera, A.C., \& Fernández, M.F. (2015). Tourism and income distribution: Evidence from a developed regional economy. Tourism Management, 48, 11-20.

Jiang, M., DeLacy, T., Mkiramweni, N.P., \& Harrison, D. (2011). Some evidence for tourism alleviating poverty. Annals of Tourism Research, 38(3), 1181-1184.

Job, H., \& Paesler, F. (2013). Links between nature-based tourism, protected areas, poverty alleviation and crises - the example of wasini island (kenya). Journal of Outdoor Recreation and Tourism, 1, 18-28.

Johansen, S. (1991). Estimation and hypothesis testing of cointegration vectors in gaussian vector autoregressive models. Econometrica: Journal of the Econometric Society, 1551-1580.

Kinyondo, A., \& Pelizzo, R. (2015). Tourism, development and inequality: The case of Tanzania. Poverty \& Public Policy, 7(1), 64-79. 
Lee, S. (2009). Income inequality in tourism services-dependent counties. Current Issues in Tourism, $12(1), 33-45$.

Lee, S., \& O'Leary, J.T. (2008). Determinants of income inequality in us nonmetropolitan tourism-and recreation-dependent communities. Journal of Travel Research, 46(4), 456-468.

Li, H., Chen, J.L., Li, G., \& Goh, C. (2016). Tourism and regional income inequality: Evidence from China. Annals of Tourism Research, 58, 81-99.

Li, H., Goh, C., Zhang Qiu, H., \& Meng, F. (2015). Effect of tourism on balanced regional development: A dynamic panel data analysis in coastal and inland china. Asia Pacific Journal of Tourism Research, 20(6), 694-713.

Loizides, J., \& Vamvoukas, G. (2005). Government expenditure and economic growth: Evidence from trivariate causality testing. Journal of Applied Economics, 8(1), 125-152.

Maddala, G.S., \& Wu, S. (1999). A comparative study of unit root tests with panel data and a new simple test. Oxford Bulletin of Economics and statistics, 61(S1), 631-652.

Manyara, G., \& Jones, E. (2007). Community-based tourism enterprises development in kenya: An exploration of their potential as avenues of poverty reduction. Journal of sustainable tourism, $15(6), 628-644$.

Marcouiller, D.W., Kim, K.-K., \& Deller, S.C. (2004). Natural amenities, tourism and income distribution. Annals of tourism research, 31(4), 1031-1050.

Paramati, S.R., Alam, M.S., \& Chen, C.F. (2016). The effects of tourism on economic growth and $\mathrm{CO}_{2}$ emissions: A comparison between developed and developing economies. Journal of Travel Research (forthcoming).

Paramati, S.R., Ummalla, M., \& Apergis, N. (2016). The effect of foreign direct investment and stock market growth on clean energy use across a panel of emerging market economies. Energy Economics 56, 29-41.

Pedroni, P. (2000). Fully modified OLS for heterogeneous cointegrated panels. Advances in Econometrics 15, 93-130.

Pedroni, P. (2001). Purchasing power parity tests in cointegrated panels. Review of Economics and Statistics 83(4), 727-731.

Pesaran, M. (2004). General diagnostic tests for cross section dependence in panels.

Pesaran, M.H. (2007). A simple panel unit root test in the presence of cross-section dependence. Journal of Applied Econometrics, 22(2), 265-312.

Scheyvens, R., \& Momsen, J.H. (2008). Tourism and poverty reduction: Issues for small island states. Tourism Geographies, 10(1), 22-41.

Schilcher, D. (2007). Growth versus equity: The continuum of pro-poor tourism and neoliberal governance. Current Issues in Tourism, 10(2-3), 166-193.

Sharpley, R., \& Naidoo, P. (2010). Tourism and poverty reduction: The case of mauritius. Tourism and Hospitality Planning \& Development, 7(2), 145-162.

Stern, D.I. (1993). Energy and economic growth in the USA: A multivariate approach. Energy Economics, 15(2), 137-150.

Tosun, C., Timothy, D.J., \& Öztürk, Y. (2003). Tourism growth, national development and regional inequality in turkey. Journal of Sustainable Tourism, 11(2-3), 133-161.

Truong, V.D., Hall, C.M., \& Garry, T. (2014). Tourism and poverty alleviation: Perceptions and experiences of poor people in sapa, vietnam. Journal of Sustainable Tourism, 22(7), 10711089. 
WDI (2015). 'World Development Indicators', World Bank, Washington, DC. United States. Accessed at: http://www. worldbank.org/data/onlinedatabases/onlinedatabases.html

Wen, J., \& Tisdell, C. (1997). Regional inequality and tourism distribution in china. Pacific Tourism Review, 1(2), 119-128.

WTTC (2015). Travel \& Tourism: Economic Impact 2015 World. London, United Kingdom: WTTC. 
Table 1: Average annual growth rates, 1991-2012 (percent)

\begin{tabular}{|c|c|c|c|c|c|c|c|c|c|c|c|c|c|}
\hline S. No & Country & IIE & FDI & GDPPC & TO & TR & S. No & Country & IIE & FDI & GDPPC & TO & TR \\
\hline 1 & Argentina & -0.33 & 22.46 & 2.93 & 5.14 & 0.84 & 26 & Malawi & -1.56 & 100.44 & 1.37 & 5.23 & 10.58 \\
\hline 2 & Armenia & 0.26 & 63.25 & 4.72 & -1.10 & 5.19 & 27 & Malaysia & 0.30 & 376.30 & 3.49 & 0.19 & 2.01 \\
\hline 3 & Bangladesh & 1.16 & 102.61 & 3.64 & 5.05 & 1.35 & 28 & Mali & -0.86 & 144.77 & 1.88 & 2.31 & 2.22 \\
\hline 4 & Belarus & 0.19 & 71.47 & 3.91 & 5.77 & 23.10 & 29 & Mexico & -0.23 & 5.48 & 1.24 & 3.88 & 0.23 \\
\hline 5 & Brazil & -0.59 & 21.83 & 1.90 & 2.54 & -0.82 & 30 & Moldova & 0.39 & 25.94 & -0.57 & 4.73 & 18.10 \\
\hline 6 & Bulgaria & 1.58 & 28.39 & 2.90 & 3.05 & -0.32 & 31 & Nigeria & -0.15 & 8.53 & 3.03 & 0.53 & 4.47 \\
\hline 8 & Colombia & 0.04 & 19.95 & 1.97 & 0.56 & 1.78 & 33 & Paraguay & 1.01 & 121.50 & 0.76 & 0.97 & 3.29 \\
\hline 9 & Costa Rica & 0.50 & 7.43 & 2.86 & 0.73 & 0.83 & 34 & Peru & -0.44 & 11.25 & 3.56 & 3.40 & 3.62 \\
\hline 10 & Dominican Republic & -0.17 & 22.72 & 3.83 & -1.37 & 0.73 & 35 & Philippines & 0.19 & 55.95 & 2.11 & 0.56 & 3.09 \\
\hline 11 & Ecuador & -0.70 & -66.59 & 1.41 & 1.99 & -9.31 & 36 & Romania & 1.57 & 35.94 & 2.81 & 4.89 & 1.17 \\
\hline 12 & Egypt & -0.09 & 1.81 & 2.82 & -1.33 & 1.89 & 37 & Rwanda & 1.80 & 6176.80 & 3.51 & 7.88 & 14.86 \\
\hline 13 & El Salvador & -0.59 & 90.36 & 2.40 & 2.11 & 3.79 & 38 & Sierra Leone & -2.51 & 392.89 & 1.02 & 4.56 & 5.90 \\
\hline 14 & Ethiopia & 0.25 & 205.98 & 3.81 & 7.59 & 7.76 & 39 & South Africa & 0.20 & 278.02 & 1.02 & 2.49 & 3.99 \\
\hline 16 & Guatemala & -0.36 & 38.10 & 1.26 & 2.58 & 2.60 & 41 & Thailand & -0.73 & 25.67 & 3.43 & 3.38 & 2.61 \\
\hline 17 & Honduras & 0.02 & 14.18 & 1.24 & 3.05 & 5.42 & 42 & Tunisia & -0.17 & 39.40 & 3.10 & 1.34 & 2.21 \\
\hline 18 & Hungary & -0.19 & 48.04 & 1.97 & 5.67 & 2.15 & 43 & Turkey & -0.64 & 26.40 & 2.70 & 3.66 & 3.82 \\
\hline 19 & India & 0.27 & 34.88 & 5.09 & 6.18 & -0.73 & 44 & Uganda & 0.39 & 92.08 & 3.56 & 3.36 & 15.33 \\
\hline 20 & Indonesia & 0.95 & -4.50 & 3.24 & 1.58 & -0.54 & 45 & Ukraine & 2.32 & 24.95 & -0.19 & 4.36 & 50.98 \\
\hline 21 & Iran & -0.92 & 97.80 & 2.10 & 1.10 & 20.64 & 46 & Venezuela & -0.39 & 34.58 & 0.79 & 0.03 & 1.41 \\
\hline 22 & Jordan & -0.96 & 108.35 & 2.79 & -0.33 & 0.75 & 47 & Vietnam & 0.66 & 6.45 & 5.62 & 4.44 & 3.95 \\
\hline 23 & Kazakhstan & 0.34 & 69.83 & 3.35 & -2.06 & 1.73 & 48 & Zambia & 0.29 & 43.54 & 2.24 & 0.96 & 1.60 \\
\hline 24 & Kyrgyz Republic & 0.49 & 63.69 & -0.12 & 3.77 & 5.16 & 49 & Zimbabwe & -0.11 & 141.23 & -1.55 & 3.53 & 12.36 \\
\hline 25 & Macedonia & 1.72 & 60.70 & 1.18 & 6.74 & 7.11 & & & & & & & \\
\hline
\end{tabular}

Note: Growth rates are calculated using original data. 
Table 2: Mean statistics for individual countries, 1991-2012

\begin{tabular}{|c|c|c|c|c|c|c|c|c|c|c|c|c|c|}
\hline S. No & Country & IIE & FDI & GDPPC & TO & TR & S. No & Country & IIE & FDI & GDPPC & TO & TR \\
\hline 1 & Argentina & 43.13 & 2.30 & 5807.33 & 27.55 & 9.85 & 26 & Malawi & 46.52 & 1.82 & 219.40 & 67.95 & 6.45 \\
\hline 2 & Armenia & 38.40 & 4.75 & 1291.58 & 77.53 & 5.69 & 27 & Malaysia & 42.73 & 4.32 & 5085.20 & 186.16 & 14.83 \\
\hline 3 & Bangladesh & 37.89 & 0.48 & 456.36 & 31.60 & 4.16 & 28 & Mali & 38.77 & 2.80 & 409.65 & 62.78 & 8.44 \\
\hline 4 & Belarus & 26.26 & 1.75 & 2802.42 & 127.47 & 5.18 & 29 & Mexico & 46.52 & 2.41 & 7526.92 & 50.20 & 13.62 \\
\hline 5 & Brazil & 49.99 & 2.31 & 4702.82 & 22.50 & 9.85 & 30 & Moldova & 38.00 & 4.30 & 813.59 & 117.54 & 5.27 \\
\hline 6 & Bulgaria & 29.52 & 7.46 & 3386.31 & 98.19 & 18.14 & 31 & Nigeria & 44.61 & 3.77 & 703.65 & 60.42 & 4.05 \\
\hline 7 & China & 49.14 & 4.02 & 1546.73 & 44.40 & 11.50 & 32 & Panama & 49.34 & 6.89 & 4569.84 & 156.65 & 8.24 \\
\hline 8 & Colombia & 49.88 & 2.98 & 3360.86 & 35.64 & 5.08 & 33 & Paraguay & 48.04 & 1.31 & 1559.58 & 99.50 & 3.43 \\
\hline 9 & Costa Rica & 43.50 & 4.09 & 4368.50 & 87.89 & 13.92 & 34 & Peru & 51.14 & 3.82 & 2636.92 & 39.73 & 7.88 \\
\hline 10 & Dominican Republic & 45.37 & 3.38 & 3355.05 & 71.98 & 16.56 & 35 & Philippines & 42.71 & 1.51 & 1146.72 & 85.38 & 9.80 \\
\hline 11 & Ecuador & 48.81 & 1.62 & 2917.93 & 52.15 & 15.55 & 36 & Romania & 28.84 & 3.26 & 4243.18 & 68.34 & 5.00 \\
\hline 12 & Egypt & 32.46 & 2.39 & 1189.44 & 51.31 & 14.81 & 37 & Rwanda & 43.42 & 0.71 & 265.58 & 35.86 & 5.09 \\
\hline 13 & El Salvador & 44.38 & 1.93 & 2583.03 & 64.56 & 5.96 & 38 & Sierra Leone & 46.32 & 3.65 & 319.33 & 48.58 & 5.51 \\
\hline 14 & Ethiopia & 31.93 & 1.81 & 163.37 & 35.40 & 7.34 & 39 & South Africa & 56.87 & 1.30 & 5222.18 & 51.88 & 7.65 \\
\hline 15 & Fiji & 31.96 & 5.16 & 3364.29 & 120.97 & 32.49 & 40 & Sri Lanka & 36.64 & 1.31 & 1156.43 & 72.48 & 8.02 \\
\hline 16 & Guatemala & 49.00 & 1.49 & 2089.81 & 55.33 & 6.82 & 41 & Thailand & 42.01 & 2.99 & 2482.93 & 116.73 & 15.35 \\
\hline 17 & Honduras & 50.03 & 4.04 & 1322.85 & 108.95 & 10.87 & 42 & Tunisia & 37.38 & 2.95 & 2939.47 & 91.52 & 17.08 \\
\hline 18 & Hungary & 28.58 & 9.15 & 9488.38 & 116.78 & 11.48 & 43 & Turkey & 40.94 & 1.19 & 6478.55 & 46.13 & 10.16 \\
\hline 19 & India & 49.24 & 1.10 & 674.77 & 32.90 & 7.70 & 44 & Uganda & 39.21 & 3.25 & 295.49 & 38.60 & 5.87 \\
\hline 20 & Indonesia & 34.51 & 0.98 & 1235.90 & 57.55 & 11.07 & 45 & Ukraine & 29.99 & 2.90 & 1691.45 & 93.29 & 7.56 \\
\hline 21 & Iran & 41.54 & 0.71 & 2491.13 & 45.08 & 6.49 & 46 & Venezuela & 40.39 & 1.98 & 5632.73 & 50.90 & 8.12 \\
\hline 22 & Jordan & 37.37 & 6.13 & 2186.03 & 124.81 & 21.70 & 47 & Vietnam & 36.62 & 6.07 & 608.32 & 112.90 & 9.53 \\
\hline 23 & Kazakhstan & 31.78 & 7.10 & 3218.41 & 90.81 & 5.44 & 48 & Zambia & 51.77 & 5.00 & 715.30 & 65.72 & 5.25 \\
\hline 24 & Kyrgyz Republic & 38.78 & 3.98 & 474.56 & 100.29 & 4.84 & 49 & Zimbabwe & 53.66 & 1.32 & 561.70 & 79.63 & 7.33 \\
\hline 25 & Macedonia & 32.49 & 3.48 & 2943.21 & 88.56 & 3.85 & & & & & & & \\
\hline
\end{tabular}

Note: Mean statistics are calculated using original data. 
Table 3: Preliminary statistics

\begin{tabular}{lllll|lllll}
\hline \multirow{2}{*}{ Variables } & \multicolumn{3}{c|}{ Summary statistics } & \multicolumn{5}{c}{ Unconditional correlations } \\
\cline { 2 - 10 } & Mean & Std. Dev. & Min. & Max. & IIE & FDI & GDPPC & TO & TR \\
\hline IIE & 41.395 & 8.085 & 19.960 & 60.820 & 1.000 & & & & \\
FDI & 3.172 & 3.830 & -16.150 & 50.970 & -0.067 & 1.000 & & & \\
GDPPC & 2545.003 & 2177.280 & 113.880 & 11749.750 & -0.022 & 0.239 & 1.000 & & \\
TO & 74.876 & 38.359 & 10.750 & 220.410 & -0.261 & 0.378 & 0.202 & 1.000 & \\
TR & 9.508 & 6.215 & 0.300 & 53.100 & -0.026 & 0.348 & 0.370 & 0.225 & 1.000 \\
\hline
\end{tabular}

Note: Summary statistics and unconditional correlations are calculated using original data and log data, respectively.

Table 4: Tests for cross-sectional dependence and unit root

\begin{tabular}{lllllll}
\hline Variable & CD test & $\mathrm{p}$-value & \multicolumn{4}{c}{ CIPS test } \\
\cline { 4 - 7 } & & & Level & $\mathrm{p}$-value & 1st difference & $\mathrm{p}$-value \\
\hline IIE & $8.120^{* * *}$ & 0.000 & -0.266 & 0.395 & $-1.749^{* *}$ & 0.040 \\
FDI & $41.220^{* * *}$ & 0.000 & -0.215 & 0.415 & $-16.449^{* * *}$ & 0.000 \\
GDPPC & $118.100^{* * *}$ & 0.000 & 0.177 & 0.570 & $-5.305^{* * *}$ & 0.000 \\
TO & $36.510^{* * *}$ & 0.000 & -0.995 & 0.160 & $-7.890^{* * *}$ & 0.000 \\
TR & $52.630^{* * *}$ & 0.000 & -0.988 & 0.162 & $-11.286^{* * *}$ & 0.000 \\
\hline
\end{tabular}

Notes: '**' \& '***' indicates the rejection of the null hypothesis of cross-sectional independence (CD test) and the null hypothesis of the unit root at $5 \%$ and $1 \%$ significance level, respectively.

CIPS test is estimated using constant and lag length is chosen based on SIC.

Table 5: Fisher-type Johansen panel co-integration test results

\begin{tabular}{lcccc}
\hline Ho & \multicolumn{2}{c}{ Fisher Stat. $^{\mathrm{a}}$} & \multicolumn{2}{c}{ Fisher Stat. $^{\mathrm{a}}$} \\
\cline { 2 - 5 } & (from trace test) & Prob. & (from max-eigen test) $^{\text {Prob. }}$ \\
\hline None & $354.700^{* * *}$ & 0.000 & $354.700 * * *$ & 0.000 \\
At most 1 & $1470.000^{* * *}$ & 0.000 & $1044.000^{* * *}$ & 0.000 \\
At most 2 & $921.100^{* * *}$ & 0.000 & $751.100 * * *$ & 0.000 \\
At most 3 & $579.500^{* * *}$ & 0.000 & $512.500^{* * *}$ & 0.000 \\
At most 4 & $319.500^{* * *}$ & 0.000 & $319.500 * * *$ & 0.000 \\
\hline
\end{tabular}

Notes: Variables: IIE, FDI, GDPPC, TO \& TR;

Trend assumption: No deterministic trend;

Lag selection: Based on SIC;

a Probabilities are computed using asymptotic Chi-square distribution;

$* * *$ denotes rejection of null hypothesis of no co-integration at the $1 \%$ significance level. 
Table 6: Analysis of long-run income inequality elasticities

\begin{tabular}{lllllll}
\hline Variable & \multicolumn{2}{l}{$I I E=F(F D I, G D P P C, T O, T R)$} & \multicolumn{3}{l}{$I I E=F\left(F D I, G D P P C, T O, T R, T R^{2}\right)$} \\
\cline { 2 - 7 } & Coefficient & t-Statistic & Prob. & Coefficient & t-Statistic & Prob. \\
\hline FDI & $0.003^{* * *}$ & 5.814 & 0.000 & $0.006^{* * *}$ & 18.957 & 0.000 \\
GDPPC & $-0.047^{* * *}$ & -5.199 & 0.000 & $-0.121^{* * *}$ & -47.682 & 0.000 \\
TO & $0.009^{* *}$ & 2.456 & 0.014 & $0.014 * * *$ & 7.290 & 0.000 \\
TR & $0.017 * * *$ & 4.522 & 0.000 & $0.604 * * *$ & 14.486 & 0.000 \\
TR $^{2}$ & & & & $-0.115^{* * *}$ & -14.447 & 0.000 \\
\hline
\end{tabular}

Notes: '**' $\&$ '***' denote the significance level at the $5 \%$ and $1 \%$, respectively;

Long-run elasticities are estimated using FMOLS.

Table 7: Fixed effect model (Dependent variable: income inequality)

\begin{tabular}{llll}
\hline Variable & Coefficient & t-Statistic & Prob. \\
\hline Constant & $3.262 * * *$ & 28.616 & 0.000 \\
FDI & 0.002 & 1.617 & 0.107 \\
GDPPC & $0.028 * *$ & 2.270 & 0.024 \\
INF & $0.003 *$ & 1.872 & 0.063 \\
PR & 0.003 & 0.889 & 0.375 \\
TO & -0.001 & -0.078 & 0.938 \\
TR & $0.022 * * *$ & 2.652 & 0.009 \\
TTC & $0.107 * * *$ & 4.306 & 0.000 \\
UNE & $0.014 * *$ & 2.514 & 0.013
\end{tabular}

Note: $* * *$ and $* * *$ indicates the significance at the $10 \%, 5 \%$ and $1 \%$ levels, respectively.

Table 8: Heterogeneous panel causality test results

\begin{tabular}{llll}
\hline Null Hypothesis: & Zbar-Stat. & Prob. & Lags \\
\hline FDI does not homogeneously cause IIE & $-2.312^{* *}$ & 0.021 & 2 \\
IIE does not homogeneously cause FDI & -0.169 & 0.866 & 2 \\
GDPPC does not homogeneously cause IIE & $4.988^{* * *}$ & 0.000 & 1 \\
IIE does not homogeneously cause GDPPC & $4.900^{* * *}$ & 0.000 & 1 \\
TO does not homogeneously cause IIE & -0.469 & 0.639 & 1 \\
IIE does not homogeneously cause TO & 0.893 & 0.372 & 1 \\
TR does not homogeneously cause IIE & -0.861 & 0.389 & 2 \\
IIE does not homogeneously cause TR & $5.922^{* * *}$ & 0.000 & 2
\end{tabular}

Note: '**’ \& ‘***' denotes rejection of the null hypothesis of no causality at the $5 \%$ and $1 \%$ significance levels, respectively. 